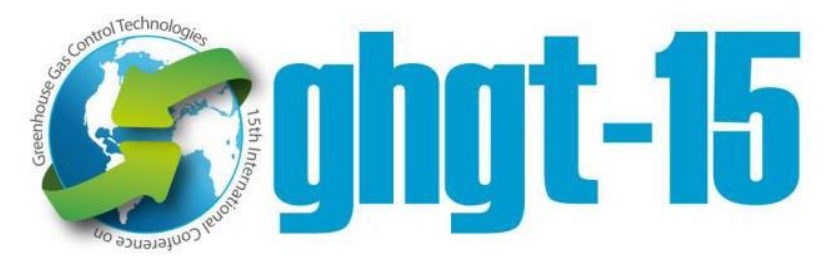

15th International Conference on Greenhouse Gas Control Technologies, GHGT-15

$15^{\text {th }} 18^{\text {th }}$ March 2021 Abu Dhabi, UAE

\title{
The Geological Potential of the Arabian Plate for CCS and CCUS An Overview
}

\author{
Volker Vahrenkamp*, Abdulkader Afifi, Alexandros Tasianas and Hussein Hoteit \\ King Abdullah University of Science and Technology (KAUST), Thuwal 23955-6900, Saudi Arabia
}

\begin{abstract}
Given allowable carbon emissions for reaching climate targets, CCS and CCUS are without alternatives to simultaneously maintain a supply of sufficient energy for the world and preventing stranded subsurface assets for hydrocarbon producing countries. Permanent storage of carbon dioxide $\left(\mathrm{CO}_{2}\right)$ in deep subsurface formations is acknowledged as a scalable and achievable technology to contribute to the ongoing efforts of limiting $\mathrm{CO}_{2}$ emissions and possibly lead to the use of stored $\mathrm{CO}_{2}$ for geothermal energy generation. The sequestration processes include entrapping $\mathrm{CO}_{2}$ in saline aquifers and hydrocarbon reservoirs in its mobile phase and in basalts as carbonate minerals. So, what are then the geological subsurface opportunities in Arabia for $\mathrm{CO}_{2}$ sequestration? A high level assessment has been conducted to identify geological formations suitable for storing and utilizing $\mathrm{CO}_{2}$ on a large scale.

Over the Arabian peninsula four significantly different geological terrains are likely suitable for CCS \& CCUS: (1) An Eastern section of stacked Mesozoic aquifers along the coast and inland of the Arabian Gulf, (2) rift basins with deep saline aquifers along the Red Sea, (3) Cenozoic volcanic rocks inland of the Red Sea coast, and Proterozoic ultramafic rocks in the Arabian Shield, and (4) a fringe of Cretaceous obducted marine crust (ophiolites) in Northeastern Oman and the UAE.

The potential of the North-Eastern section for retaining $\mathrm{CO}_{2}$ in the subsurface is essentially manifested by the presence of many super giant oil reservoirs in stacked, layered limestone sequences of mainly Mesozoic age. During this time period the eastern part of the Arabian plate was at a passive continental margin in a near-equatorial location resulting in mainly limestone deposition over very large areas. The overall architecture of cyclic carbonate deposition, interrupted by the incursion of thick layers of evaporites (e.g. Tithonian Hith Anhydrite) and shales (e.g. Albian Nahr Umr FM), has produced an ideal combination of multiple stacked reservoirs/aquifers overlain by seals. Gentle folding has created numerous structures for the permanent entrapment of migrating hydrocarbons but also light fluids such as supercritical $\mathrm{CO}_{2}$. Aquifer porosity and permeability are typically around $20 \%$ and $10 \mathrm{mD}$ - $100 \mathrm{mD}$ respectively, but can reach up to $40 \%$ porosity and Darcy-scale permeability. Aquifer fluids are typically highly saline reaching concentrations of 5 times seawater or more. The favorable conditions of relatively high porosity and permeability can exist to several $\mathrm{km}$ depth at which the formation temperatures reach $150^{\circ} \mathrm{C}$ and sometimes beyond. This not only offers the possibility for $\mathrm{CO}_{2}$ storage but also utilization as a geothermal source for electricity generation and other heat-energy utilization processes, such as desalination and district cooling. Similar favorable geological conditions for CCS and CCUS are likely present in the rift basins along the Red Sea Coast albeit at a smaller scale and less well explored. Rift basins reach 6km in depth and are filled with continental and marine clastic and carbonate sediments, salt and shale layers can provide seal capacity. Opportunities for CCUS and geothermal energy generation are likely to exist near the populated and industrialized centers along the Red Sea.

Thick stacked basaltic lava flows inland of the Red Sea coast (Harrats) and ophiolites associated with seafloor obduction along the North-Eastern margin of the plate in Oman and the UAE offer opportunities for $\mathrm{CO}_{2}$ sequestration in its solid phase.

Keywords: Arabian Peninsula; CCS, CCUS, subsurface $\mathrm{CO}_{2}$ storage; deep aquifer; seals; stacked basalts; geothermal energy.
\end{abstract}

\footnotetext{
* Corresponding author. Email address: volker.vahrenkamp@kaust.edu.sa
} 


\section{Introduction}

The countries of the Arabian Peninsula (Saudi Arabia, Kuwait, Qatar, Bahrain, United Arab Emirates, Oman and Yemen) are not only major hydrocarbon producers exporting vast quantities of gas and oil into the world, but also major consumers of energy derived almost completely from hydrocarbons. Most countries of this area exceed energy consumption and associated $\mathrm{CO}_{2}$ emissions on a per capita base compared the United States and European countries (3). In addition to normal electricity and transportation consumption this is owed basically to three factors: firstly, the need for cooling to cope with the excessive temperatures of Arabia, secondly, the dependency on desalinated water caused by the lack of rain and the depletion of groundwater resources and thirdly, the readily available hydrocarbon resources, which are produced inexpensively, and sold cheaply. Yet it is recognized that rising temperatures associated with anthropogenic climate change will have a significant negative impact on Arabian societies (4-6). Hence governments of the region have supported the Paris climate accord and are taking steps towards mitigating climate change through the development of non-hydrocarbon-based energy sources (7) and CCS and CCUS techniques (8). Recently, Saudi Arabia has initiated the Circular Carbon Economy (CCE), which is a comprehensive framework to address the dual challenge of energy and the environment by adopting four principles (4Rs), corresponding to Reduce, Reuse, Recycle, and Remove (9).

However, Arabian societies will for the foreseeable future contribute significantly to world-wide $\mathrm{CO}_{2}$ emissions through internal hydrocarbon consumption and their dependency on the export of hydrocarbons to create income for their economies. This is likely to occur even if efficiencies improve (5) and alternative energy sources are developed.

This paper evaluates this conundrum and looks at solutions to mitigate $\mathrm{CO}_{2}$ emissions without leaving hydrocarbon assets stranded in the subsurface. First, a simple overview is presented of carbon budgets based on hydrocarbon reserves and current annual production and consumption. Secondly, the geological potential for CCS and CCUS technologies is assessed for the Arabian Peninsula. Thirdly, a long-term holistic concept is proposed to utilize $\mathrm{CO}_{2}$ stored in the subsurface for electricity production using geothermal energy concepts. In addition to geothermal energy generation, subsurface storage of $\mathrm{CO}_{2}$ furthermore provides two additional major advantages: a secondary utilization loop for ultimately using the stored $\mathrm{CO}_{2}$ for large scale $\mathrm{CO}_{2}$-based enhanced oil recovery $\left(\mathrm{CO}_{2}\right.$-EOR).

\subsection{Definition of Carbon Capture \& Sequestration (CCS) and Carbon Capture Utilization and Storage (CCUS)}

We define CCS here as a terminal sequestration of $\mathrm{CO}_{2}$ in the subsurface in the form of carbonate mineralization $\left(\mathrm{CO}_{2}\right.$ Sequestration in Basalt - $\left.\mathrm{CSB}\right)$ or $\mathrm{CO}_{2}$ dissolution and dispersal in deep aquifers which are not in communication with the atmosphere over geological time spans (Fig. 1a). As a result, the injected $\mathrm{CO}_{2}$ is disposed of and is not usable as a resource anymore. Consequently, CCS is a negative cash operation and needs to be offset economically by another income. CCS in Arabia will most likely rely on saline water as a medium only (subsurface brines or ocean water)
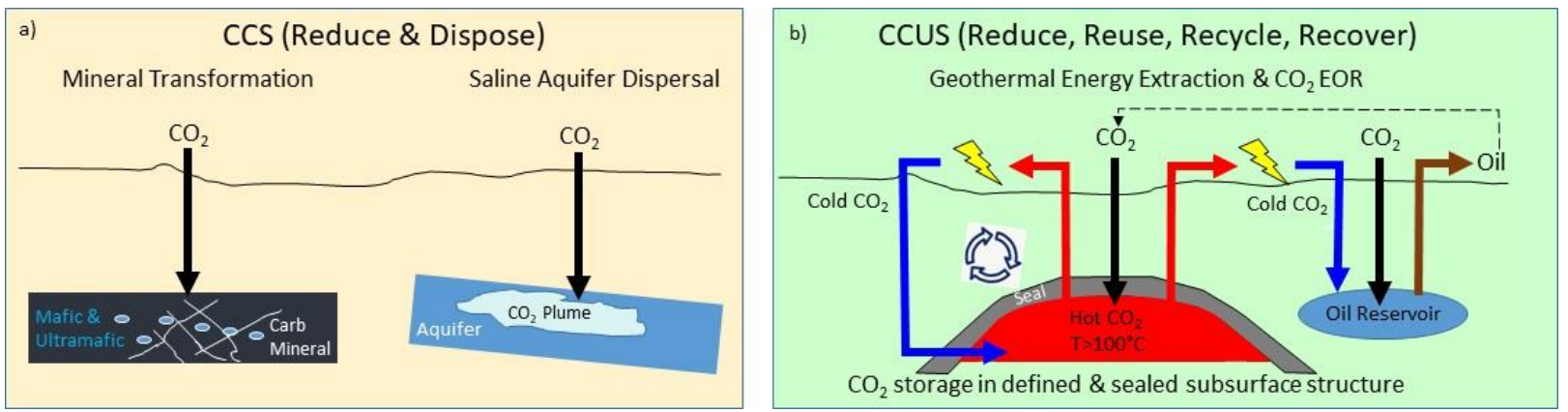

Fig. 1: Two main concepts for CCS/CCUS in Arabia. CCS technology removes $\mathrm{CO}_{2}$ using injection into saline aquifers or dispersal into mafic/ultramafic rocks to form carbonate minerals (a). CCUS targets sealed geological structures at intermediate depth (2000m+) and temperatures in excess of $100^{\circ} \mathrm{C}(\mathrm{b})$. Reuse of the stored $\mathrm{CO}_{2}$ allows geothermal energy extraction and electricity generation. $\mathrm{CO}_{2}$ based enhanced oil recovery (EOR) is a secondary CCUS loop when water-flood recovery in oil fields becomes less economical in comparison. Inherently, CCUS is preferred because it follows a "reduce, recover, reuse, recycle" strategy. 
because fresh and even brackish water aquifers are scarce and of great value as a source for drinking water and agricultural irrigation. Technical criteria for subsurface sequestration are in the case of aquifer sequestration a minimum depth of $800 \mathrm{~m}$ to keep $\mathrm{CO}_{2}$ in supercritical state, sufficient porosity and permeability to ensure storage and injectivity and the presence of seals to prevent leakage back to the surface.

CCUS technologies, on the other hand, consider $\mathrm{CO}_{2}$ as a resource that is captured, stored in the subsurface and reused for economic gain (Fig. 1b). Such technologies include, for example, geothermal energy extraction using supercritical $\mathrm{CO}_{2}$ stored in reservoirs at temperatures exceeding $100^{\circ} \mathrm{C}$ (9) or enhanced oil recovery using $\mathrm{CO}_{2}$ injection (10-12). Storage of $\mathrm{CO}_{2}$ and its reuse entail several main prerequisites: (1) geological structures are large enough and have sufficient pore space to accommodate the injected $\mathrm{CO}_{2},(2)$ seals of adequate strength can retain the $\mathrm{CO}_{2}$ in place and (3) permeabilities from matrix and/or fractures are large enough to allow an economic utilization of the stored $\mathrm{CO}_{2}$. Furthermore, while electricity generation from $\mathrm{CO}_{2}$-based geothermal is overall much more efficient compared to water-based processes it still requires temperatures in excess of about $100^{\circ} \mathrm{C}$ (13). While subsurface temperatures are a function of local geothermal gradient and lithology, this translates for most areas of the Arabian Peninsula into a minimum target depth of about $2500 \mathrm{~m}$ considering a geothermal gradient of $30-35^{\circ} \mathrm{C} / \mathrm{km}$ and an average surface temperature of about $25^{\circ} \mathrm{C}$. Potential for shallower depth will exist in areas of abnormally high gradient. A maximum target depth is dictated by the loss of porosity and permeability due to compaction and considered at about $4000 \mathrm{~m}$ albeit potential for deeper targets may also exist.

\section{Data and Methods}

Using published data, we provide an overview of reserves and current production of hydrocarbons from the Arabian Peninsula. A conversion of these data to $\mathrm{CO}_{2}$ provides insights into emission levels associated with the production of Arabian hydrocarbons and the internal consumption of countries from Arabia and a basis to compare to ongoing efforts to offset emissions.

A review of the geological potential of the Arabian Peninsula for potential sites of $\mathrm{CO}_{2}$ sequestration is the result of a review of published data. The aim of this effort is to collate all available surface and subsurface data into a common data base to produce a digital ArcGIS atlas of potential CCS and CCUS sites on the Arabian Peninsula. The progress of this work will be reported separately.

The industrial $\mathrm{CO}_{2}$ emissions database contains emissions from stationary points emitted across the country in 2015 and 2020, covering sectors of the economy such as desalination, steel, refinery \& electricity production among others.

\section{Results}

\subsection{Arabian Carbon Data}

\subsubsection{Carbon Budgets of the Arabian Peninsula}

Countries of the Arabian Peninsula are some of the major reserve holders and producers of hydrocarbons in the world. Hydrocarbon reserves of the Arabian Peninsula combined for all countries (Saudi Arabia, Kuwait, Qatar, Bahrain, United Arab Emirates, Oman, and Yemen) are estimated to amount to 754 billion barrels of oil equivalent (BOE) (Fig. 1; $(14,15)$ ). Annual production of hydrocarbons for export and internal consumption amount to about 9.5 billion BOE $(14,15)$, with internal consumption amounting to an estimated $20 \%-25 \%$ of the total (Fig. 2). Assuming that all the hydrocarbon reserves and the annual production are converted to $\mathrm{CO}_{2}$ in one way or another this will amount to a production of respectively 324 gigatons of $\mathrm{CO}_{2}$ from utilizing all reserves and 4 gigatons of $\mathrm{CO}_{2}$ per year from annual production (16). A significant part of internal hydrocarbon consumption and associated $\mathrm{CO}_{2}$ emission is associated with fixed locations, which are power plants, desalination plants, cement and steel industries, refineries, petrochemical industry, etc. (Fig. 3). Most of the remaining consumption - an estimated 35-50\% - is related to land and air mobility. 


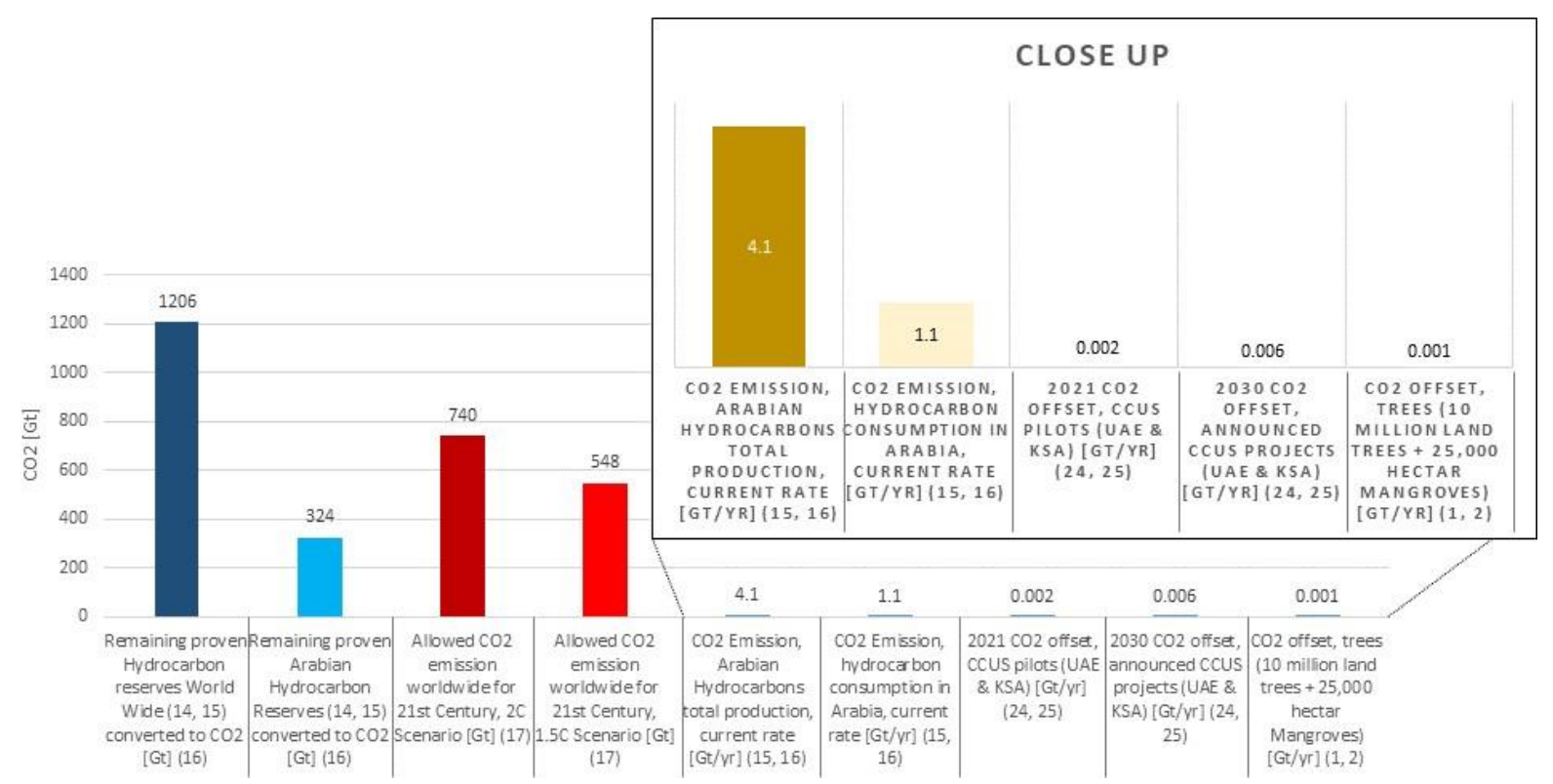

Fig. 2: Production of all booked hydrocarbon reserves of the Arabian Peninsula (Saudi Arabia, Kuwait, Qatar, UAE, Oman, Bahrain \& Yemen) will spend $44 \%$ of the worldwide remaining allowed $\mathrm{CO}_{2}$ emission to stay within a $2^{\circ} \mathrm{C}$ temperature rise, or $59 \%$ to stay within $1.5^{\circ} \mathrm{C}$ temperature rise. Assuming that the Paris accord will be met and only a smaller share of remaining $\mathrm{CO}_{2}$ emission will be available for Arabian derived $\mathrm{CO}_{2}$ this implies that the production of a substantial part of the Arabian hydrocarbon reserves should be combined with large-scale measures for $\mathrm{CO}_{2}$ removal. CCS and CCUS could offer such opportunities at the required scale. Alternatives can support but do not provide realistic offsets at scale (see offset by trees, column $9 ;(1,2)$ )

Climate models suggest that the allowed worldwide emission for $\mathrm{CO}_{2}$ is not to exceed more than 740 Gigatons of $\mathrm{CO}_{2}$ until the end of the $21^{\text {st }}$ century for a $90 \%$ chance of not increasing the world average temperature by more than $2{ }^{\circ} \mathrm{C}(17)$ ). For a $90 \%$ chance of staying within the $1.5^{\circ} \mathrm{C}$ temperature increase proposed by the Paris climate agreement, the remaining budget would have to be below an estimated 548 gigatons of $\mathrm{CO}_{2}$ (17). Hence, producing all reserves of Arabia and converting them to $\mathrm{CO}_{2}$ released into the atmosphere will consume respectively $44 \%$ or $59 \%$ of the remaining budget to have a $90 \%$ chance of not exceeding a worldwide temperature rise of $2^{\circ} \mathrm{C}$ or $1.5^{\circ} \mathrm{C}$ (Fig. 2).

Considering that other regions of this world have similar reserves and are emitting at similar rates and that coal emissions are not even considered, this is clearly an unsustainable scenario given that all countries of the Arabian Peninsula, except Yemen, have ratified the Paris climate agreement.

The clear support of governments for the Paris accord ${ }^{*}$ has been substantiated by goals to lower emissions and increase the development of alternative energy sources. Since 2016 plans have been developed and projects have been initiated for large scale power generation from Solar PV plants and wind farms $(18,19)$. There is a clear desire to further develop non-fossil fuel-related industries: renewable energy production, tourism, other industries (computing, space, etc.). However, the transition is expensive and will require long term substantial income from fossil fuel production and export.

\subsubsection{Ongoing CCS and CCUS Efforts on the Arabian Peninsula}

In order to produce and consume hydrocarbons and meet $\mathrm{CO}_{2}$ emission commitments, governments and national oil companies of the Arabian Peninsula are proposing and developing CCS and CCUS opportunities (20-23). The main CCUS technology that is being investigated is $\mathrm{CO}_{2}$ injection into reservoirs for improving oil recovery $\left(\mathrm{CO}_{2}\right.$

* On 3 November 2016, Saudi Arabia ratified the Paris Agreement, and its Intended Nationally Determined Contribution (INDC) became its NDC. The NDC aims to annually abate up to $130 \mathrm{MtCO} 2 \mathrm{e}(132 \mathrm{MtCO} 2 \mathrm{e}$ in AR4 GWPs) by 2030 through contributions that have co-benefits in diversifying the economy and mitigating greenhouse gas (GHG) emissions (Kingdom of Saudi Arabia, 2015). 


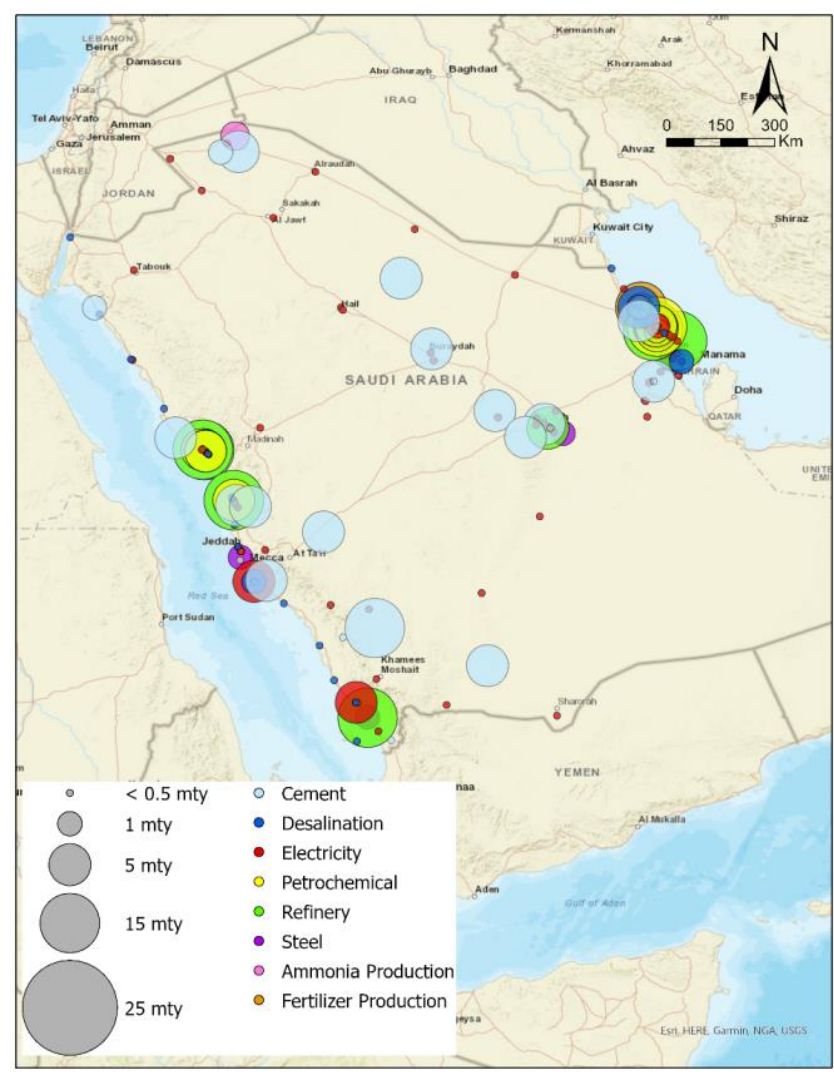

Fig. 3: $\mathrm{KSA} \mathrm{CO}_{2}$ emission from stationary sources in million tons per year (mty) in 2020 (total: 568 mty with annual growth rate $0.65 \%$ ). Similar emissions patterns are expected for other countries of the Arabian Peninsula
EOR). This results in about $60 \%$ of the injected $\mathrm{CO}_{2}$ remaining in the subsurface, while $40 \%$ is eventually reproduced as associated gas with the oil $(24,25)$. Some laboratory experiments though suggest somewhat lower percentages as viscous fingering can cause $\mathrm{CO}_{2}$ bypass of much of the pore space (Van der Meer, 1995; Ennis-King and Paterson, 2001; Flett et al., 2005). So far two $\mathrm{CO}_{2}$ EOR pilots are ongoing in the region, one in Saudi Arabia and the other in the UAE with a $\mathrm{CO}_{2}$ injection of 800,000 t/a each (Fig. 1). Plans have been formulated to increase this to at least 5 million tons per year by 2030 (26). This amount of sequestered $\mathrm{CO}_{2}$ is equivalent to $0.12 \%$ of $\mathrm{CO}_{2}$ from the hydrocarbons produced in the Arabian Peninsula per year or $0.4 \%$ of the $\mathrm{CO}_{2}$ generated within Arabia from hydrocarbon consumption per year. Furthermore, to reduce capture costs, the $\mathrm{CO}_{2}$ used for EOR is not from the conversion of hydrocarbons but almost exclusively associated $\mathrm{CO}_{2}$ gas separated as a byproduct from natural gas processing units. This $\mathrm{CO}_{2}$ is normally vented to air contributing to $\mathrm{CO}_{2}$ emissions. However, it is not offsetting any of the $\mathrm{CO}_{2}$ produced from utilizing hydrocarbons for energy generation or industrial products.

While $\mathrm{CO}_{2}$-EOR leads to the benefit of additional hydrocarbon reserves beyond those already booked, it is a complex technology with many subsurface challenges and substantial surface facilities costs (21, 27). The cost of oil produced by $\mathrm{CO}_{2}$ EOR technology is reportedly to be around $35-40 \$ / b b l$. This is not an

attractive economic solution considering the available reserves in Arabia that can be produced by much less expensive water floods. However, $\mathrm{CO}_{2}$-EOR will likely become economical at a later stage of reservoir depletion when secondary recovery methods such as water flooding have lost their economic efficiency. In any case, large scale, economically efficient $\mathrm{CO}_{2}$ EOR of super giant reservoirs common in Arabia will require enormous quantities of $\mathrm{CO}_{2}$. These exceed the volumes currently generated from point sources on an annual basis and will likely require large pools of stored $\mathrm{CO}_{2}$.

\subsection{Geological Terrains of the Arabian Peninsula for CCS and CCUS}

Four geological terrains are recognized for their potential of $\mathrm{CO}_{2}$ sequestration and/or storage (Fig. 3) and discussed separately below:

\subsubsection{Stacked sedimentary layers of the Eastern Plate Margin}

The eastern section of the Arabian Plate contains some of the largest oil reservoirs of the world in stacked, layered limestone sequences of mainly Jurassic to late Cretaceous age (Fig. 4-6). During this time period the Arabian plate was at a passive continental margin in a near equatorial location resulting in predominantly carbonate sediment deposition over very large areas (28). The bulk of the sediments were deposited in a vast shallow marine lagoon behind a platform margin that was aggrading and prograding over time from a plate interior position towards the plate margin in the East. The stacking of the sedimentary units within the area of the lagoon is rather simple with sediments having been deposited in an overall layer-cake architecture. Platform margin and slope deposits towards the Tethys Ocean are more complex in architecture. The overall architecture is of cyclic carbonate deposition and was interrupted several 


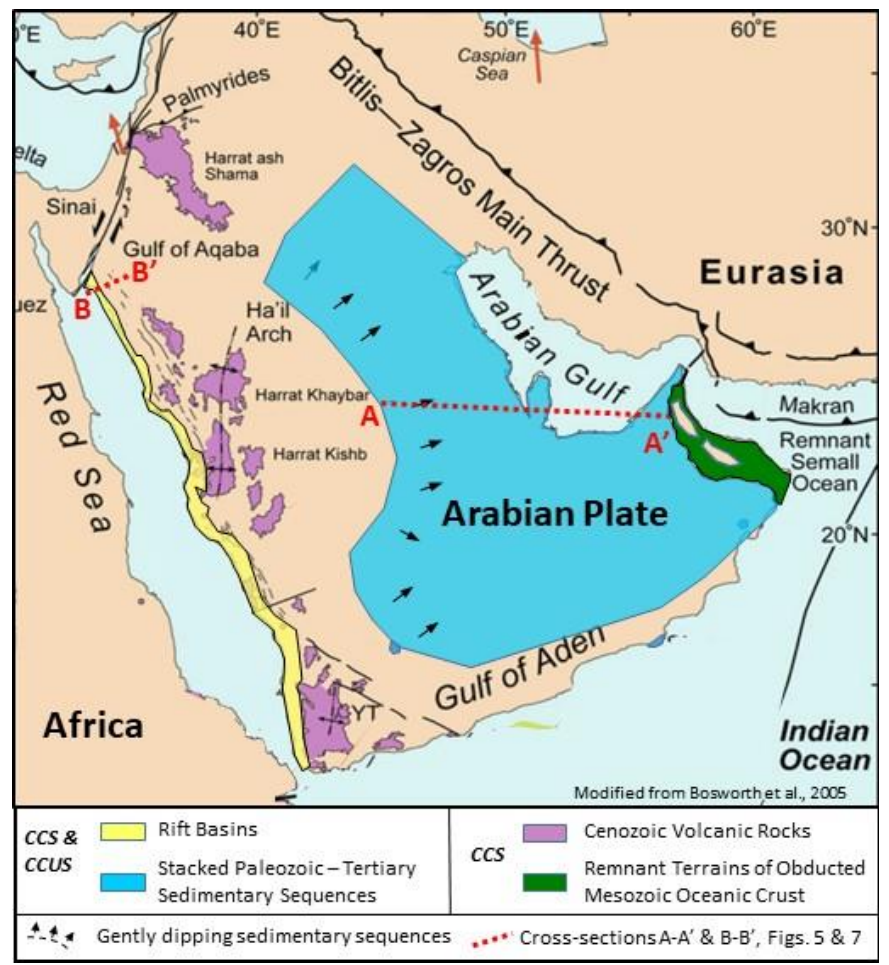

Fig. 4: Geological terrains of the Arabian Plate suitable for CCS \& CCUS (modified from 31). times by the incursion of thick evaporite (e.g. Tithonian Hith; Eocene Rus FM) and siliciclastic shale /argillaceous limestone sequences (e.g. Albian Nahr Umr FM). This has created an ideal combination of multiple stacked sequences of porous rock and overlying seals (Fig. 6). Gentle folding of the strata during the latest Cretaceous / Early Tertiary has created numerous structures ideal for the permanent entrapment of migrating hydrocarbons in the porous sequences beneath the seals (Fig. 4; $(28,29))$ However, not all structures are filled with hydrocarbons - many only contain saline waters of regional subsurface aquifers and could become the target for injecting and trapping light fluids such as hypercritical $\mathrm{CO}_{2}$.

Aquifer porosity and permeability is variable in aquifers, typically around $20 \%$ and $10 \mathrm{mD}-100 \mathrm{mD}$ respectively, but can reach values of up to $40 \%$ porosity and Darcy-scale permeability. Aquifer fluids are typically highly saline reaching concentrations of up to 5-7 times seawater or even more (30). The favorable conditions of relatively high porosity and permeability can exist to several $\mathrm{km}$ depth at which the formation temperatures reach $150^{\circ} \mathrm{C}$ and more.

The occurrence and extend of the aquifers,

reservoirs, traps, seals and their properties are generally well understood and documented in many publications (e.g. (28)). However, detailed data required for locating and evaluating potential targets for $\mathrm{CO}_{2}$ sequestration and/or storage pilots are proprietary and reside in the data bases of the National Oil Companies.

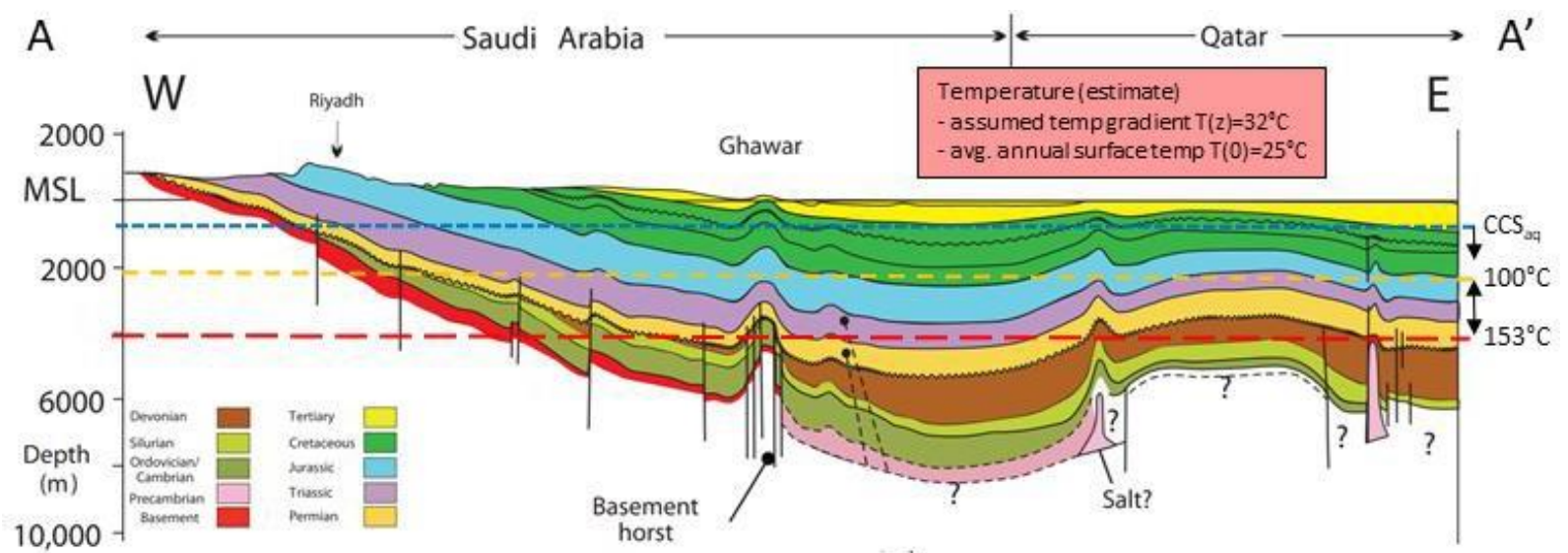

Fig. 5: CCS and CCUS opportunities in sedimentary sequences of the Eastern Arabian Peninsula. Many stacked aquifer/seal pairs offer opportunities of varying properties and qualities. CCS requires a depth of at least $800 \mathrm{~m}$ to keep the $\mathrm{CO}_{2}$ in supercritical state. Geothermal CCUS based on circulation of stored $\mathrm{CO} 2$ requires a minimum temperature of $100^{\circ} \mathrm{C}$. Late Mesozoic and Early Cenozoic deformation resulted in many gentle structures fit for carbon storage and utilization at targeted depth \& temperature ranges. Similar depositional and structural architectures exist in Kuwait, the UAE and northern Oman (modified from 32). 


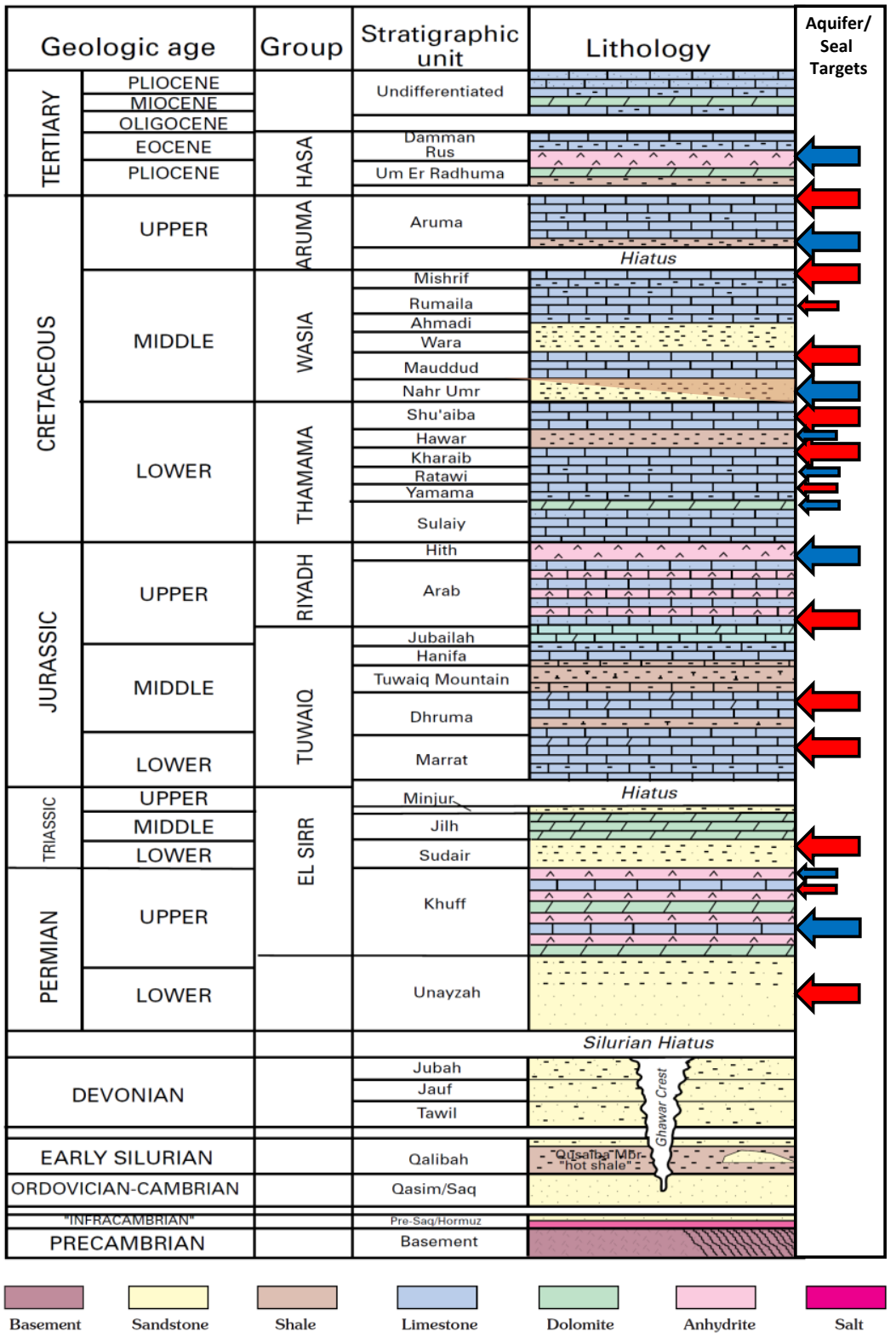

Fig. 6: The Paleozoic to Tertiary stratigraphy of the Eastern Arabian Peninsula - example from KSA. Known aquifers marked by a red arrow, seals by a blue (modified from 43).

\subsubsection{Rift Basins of the Western Plate Margin}

The African and Arabian plates started splitting and drifting apart during the Late Oligocene (31). As a consequence, up to $6 \mathrm{~km}$ deep rift basins developed along the continental margins facing the spreading center (Fig. 7; $(32,33)$ ). These rift basins were filled initially with continental clastic sediments (Red Beds) followed after a marine transgression by a thick succession of carbonates and evaporites. Incursions of siliciclastics shed from the rift margins add additional complexity to the stratigraphy (32). Sandstones, limestone and dolomites likely contain favorable porosity and permeability. Salt and shale layers provide seal capacity (33). However, the Neogene section and rift basins are characterized by significant lithologic diversity and architectural complexity as a consequence of both rift and salt tectonics (e.g. (33)). Little data has been published on geothermal temperature gradients along the western plate margin. However, gradients of $32^{\circ} \mathrm{C} / \mathrm{km}$ are to be expected with significantly higher ones in areas of geothermal springs, for example Al Lith and Jizzan in the south of the KSA Red Sea coastline (Fig. 3). This underlines the potential of these basins not only for CCS but also for CCUS and geothermal energy generation especially near

populated and industrialized centers along the Red Sea (Jizzan, Al Lith, Jeddah, Rabigh, Yanbu) with large $\mathrm{CO}_{2}$ point sources (Fig. 2). Yet, detailed mapping of suitable targets has not been done as data are not publically available for initial assessments.

\subsubsection{The Harrats of Saudi Arabia}

Mafic rocks composed mainly of alkali olivine basalts are abundant in the volcanic areas (Harrats) of western and northern Saudi Arabia where at least 14 young volcanic fields have been mapped (Fig. 8a; (34)). They consist mainly of sequences of flat lying basaltic lava flows that mantle the underlying topography, and a few felsic lava domes (trachyte, phonolite). The basaltic lavas erupted mainly from fissures and small monogenetic volcanoes (cinder and 


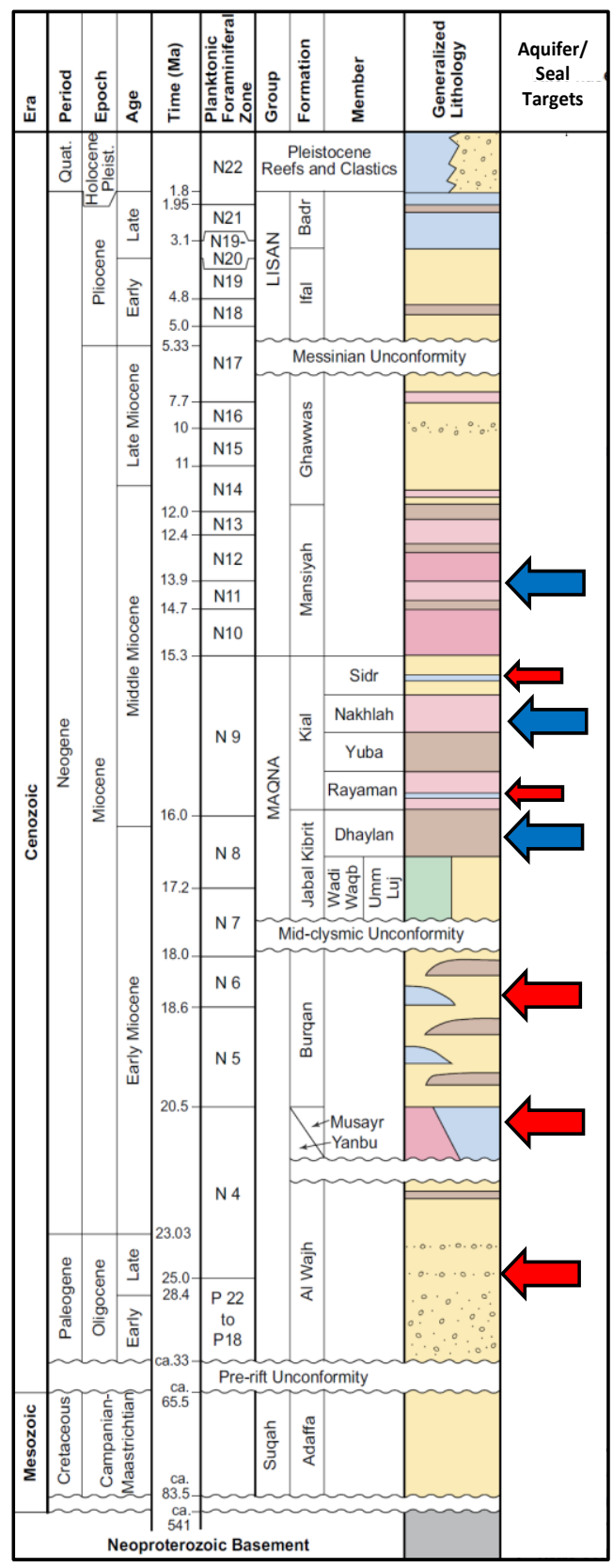

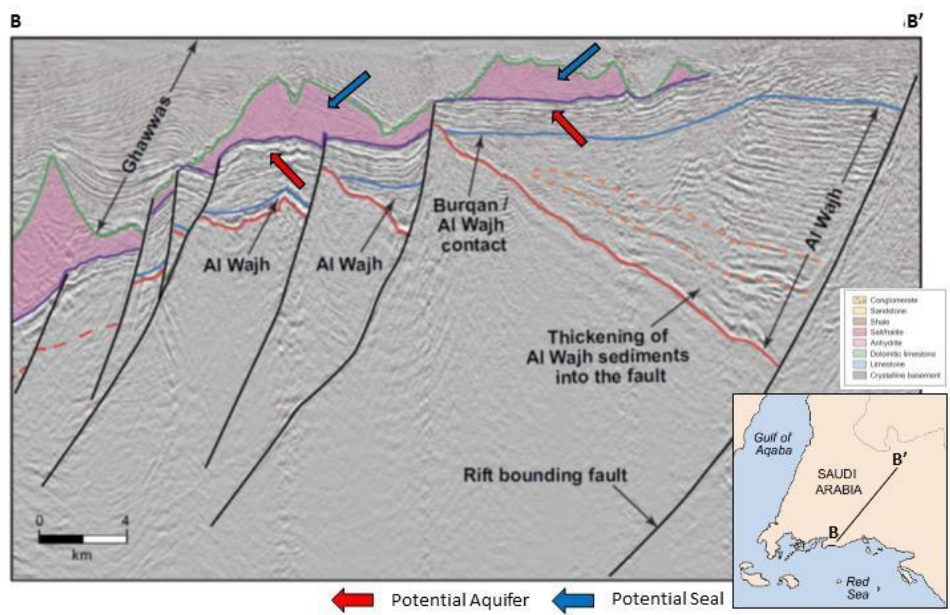

Figure 7: Typical west coast rift basin architecture with multiple aquifer/seal targets for CCS \& CCUS (modified from Tubbs et al., 2014).

spatter cones) that are aligned along structural lineation parallel to the Red Sea. The Harrats are of Oligocene to Recent age (30-0 MY) and are associated with the onset of continental rifting and a later phase with the opening of the Red Sea. The basaltic fields vary in thickness from 0 to hundreds of meters with most being less than $100 \mathrm{~m}$ thick but exceeding in places several hundred meters.

The suitability of an area for $\mathrm{CO}_{2}$ storage in basalts can be evaluated against the following parameters: geology/rock reactivity, thickness/volume of reactive rocks, sufficient effective porosity and permeability, proximity to major $\mathrm{CO}_{2}$ sources from industrial facilities, height of the groundwater column, and availability and proximity to water. Since freshwater aquifers are reserved for other purposes this implies proximity to seawater as a source. Furthermore, a potential reservoir must possess sufficient thickness of $>500 \mathrm{~m}$, with at least $400 \mathrm{~m}$ saturated with groundwater (41). To maximize the efficiency of the mineralization process, $\mathrm{CO}_{2}$ has to be co-injected with sufficient water downhole so that the gas is completely dissolved at the depth of its release into the target subsurface basalt. A similar requirement has been proposed by the Carbfix process (35). With some of the Saudi Arabian harrats being close to the coast and major industrial centers (Figs. 3, 8; Jizzan, Jeddah, Rabigh, Yanbu) significant potential likely exists for $\mathrm{CO}_{2}$ storage in basalts.

\subsubsection{The Obducted Ocean Crust of Oman and the UAE}

During the Late Cretaceous the northeastern continental margin of the Arabian plate started to collide with relatively young and hot oceanic crust that was converging from the northern Neo-Tethys towards Arabia (36) The continental margin was subducted and oceanic ophiolite crust obducted onto the continental crust $(37,38)$. Subsequent uplift in the Tertiary exposed thick sequences of ophiolite along the northeastern margin of the Arabian Peninsula in Oman and the UAE (Fig. 3, 9). The ophiolite is composed of gabbros and ultramafic rocks and reaches a thickness of more than $4 \mathrm{~km}$ (37). Paukert et al (2012) (39) calculated a high efficiency of $\mathrm{CO}_{2}$ sequestration at $90^{\circ} \mathrm{C}$ and an associated injection depth of $2 \mathrm{~km}$. The suitability for CCS in the Oman ophiolite has been evaluated by Kelemen et al. (2018) (40) who identified potential but also many uncertainties whether the process could work technically and economically. 


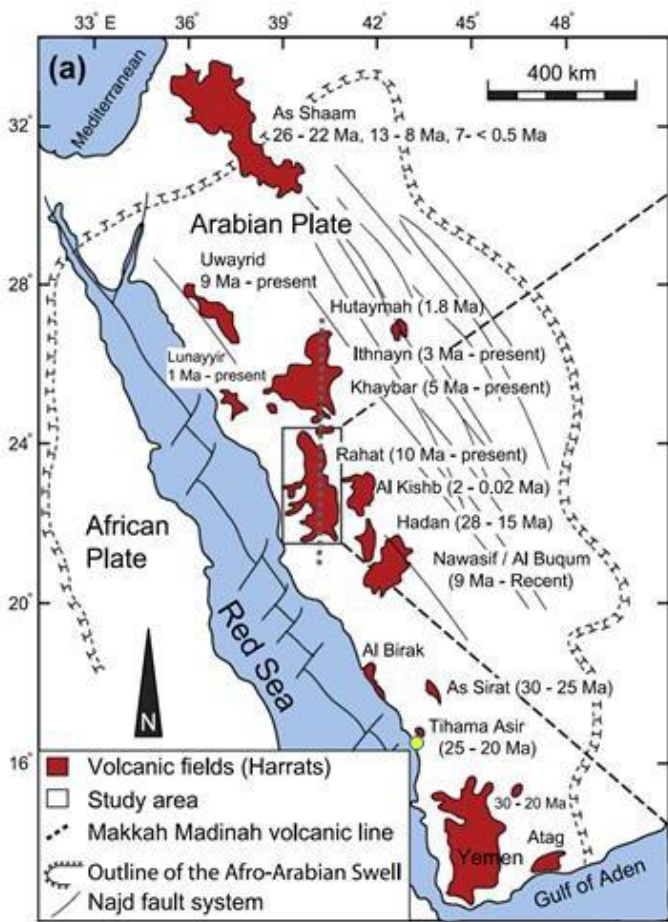

Fig. 8. Map showing in the distribution and ages of Cenozoic volcanic fields in KSA (39).

\section{Discussion}

\subsection{CCS Opportunities}

CCS opportunities are associated either with injection of $\mathrm{CO}_{2}$ into basalt or ultramafic rocks to bind the $\mathrm{CO}_{2}$ in the form of carbonate mineral precipitates (dolomite, huntite, calcite) or into saline aquifers in the eastern and western margin areas for dispersal in the subsurface. Technical criteria help in assessing subsurface potential of different geological settings such as minimum depth.

Mafic basalts and ultramafics rocks are located in the Saudi Arabian Harrats and the Oman ophiolites (Figs. 3, 8, 9). However, the process of mineralizing $\mathrm{CO}_{2}$ into carbonate minerals requires substantial amounts of water to carry the $\mathrm{CO}_{2}$ to the reaction sites at depth and to promote reactions underground. A ratio of 20:1 has been proposed for the water/ $\mathrm{CO}_{2}$ volume (41). This requires initially the sourcing of large amount of water to injection sites. In order to prevent development of overpressure at the injection level, the fluids have to be reproduced after the $\mathrm{CO}_{2}$ has reacted with the host rock. Produced water can be re-used for enrichment with $\mathrm{CO}_{2}$ and re-injected. Eventually, however, the disposal of some reproduced waters may have to be considered as well. These criteria are fulfilled with the proximity of some KSA harrats and the Oman/UAE ophiolites to nearby coasts with easy access to seawater as well as $\mathrm{CO}_{2}$ point sources from desalination and

electricity plants and other industrial facilities frequently found in coastal areas.

Shallow aquifers and geological structures for suitable $\mathrm{CO}_{2}$ sequestration can be found in both the stacked sedimentary units of Eastern Arabia and the Western rift basins. Examples in the East are the aquifer/seal pairs of the Aruma and Umr Er Rhaduma limestones / Rus Evaporites of the KSA and UAE, the Shilaif/Natih Limestones and Fiqa shales of the UAE and Oman and several other deeper aquifer/seal pairs (Fig. 6). Injection into aquifers below the regional more extensive major seal units of the Nahr Umr shales and the Hith and Khuff D anhydrites might also be possible even without lateral confinement such as 4-way dip structures as seals and aquitards are so extensive and of proven quality that leakage is highly unlikely. More proximal to the Arabian shield, the Nahr Umr Fm of the Wasia Group, transitions from a major seal composed of shales and argillaceous limestone into a sandstone aquifer potentially suitable for large scale $\mathrm{CO}_{2}$ injection and sequestration. With a total area of more than $4.8 \mathrm{E}+5 \mathrm{~km}^{2}$, an average thickness of between $200-500 \mathrm{~m}$ and porosities of $3 \%$ to $29 \%$ (42), the Wasia aquifer corresponds to a major potential target area for CCS.

On the west coast along the Red Sea, aquifer/seal pairs are less well defined but could be developed relatively shallow in the Early/Middle Miocene sandstones and limestones of the Burqan, Wadi Waqb and Umm Luj Formations with overlying Middle Miocene salt units of the Mansiyah Formation acting as seals.

\subsection{CCUS Opportunities}

Arabia probably offers the most promising geological potential for utilizing sequestered $\mathrm{CO}_{2}$ for desalination, district cooling and electricity production via geothermal heat extraction. This CCUS technology proposes the recycling of $\mathrm{CO}_{2}$ stored in intermediate depth reservoirs at temperatures between $100-150^{\circ} \mathrm{C}$. The multiple stacked aquifers, the presence of suitable seals and the favourable setting of gentle anticlinal structures combined with large numbers of point sources on the peninsula for capturing $\mathrm{CO}_{2}$ and utilizing it for optimized geothermal heat extraction, constitute a unique scenario for the successful development and large-scale deployment of CCUS technology. Successful development not only promises a steady revenue stream from stored $\mathrm{CO}_{2}$ but also provides $\mathrm{CO}_{2}$ reservoirs for a late- 

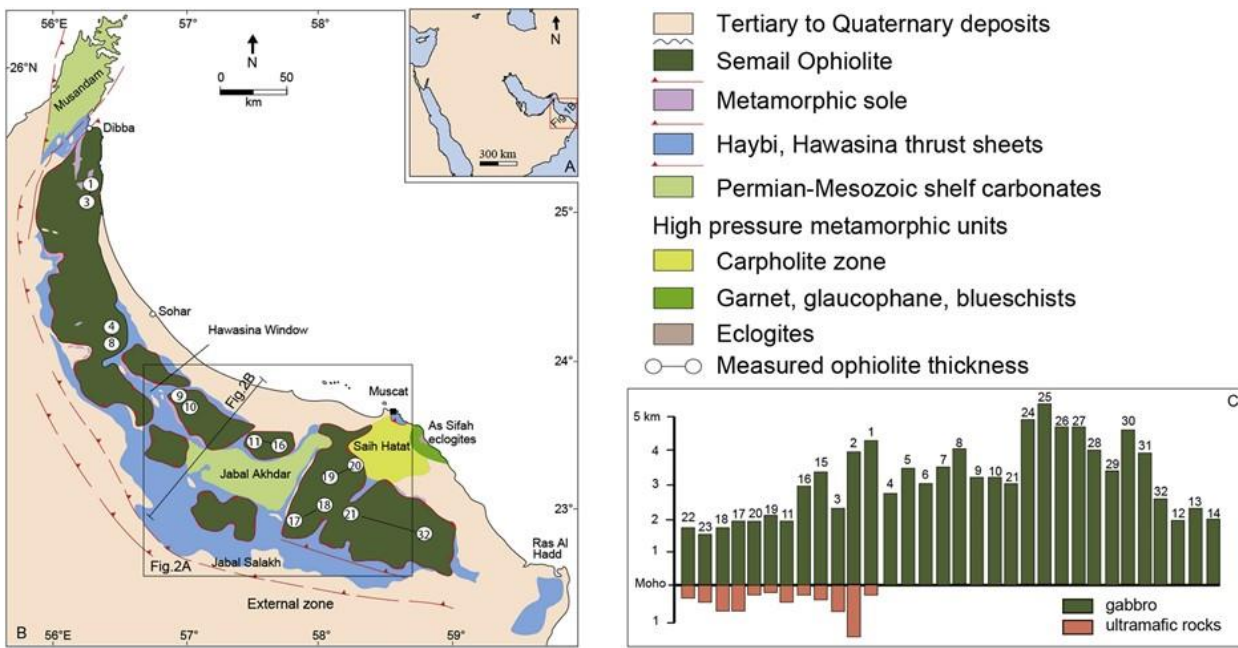

Fig. 9: Location and thickness of the Oman ophiolite and associated ultramafic rocks. Numbers above bars in (C) correspond to the location of the measured ophiolites shown in B (Fig. 1 of 43). stage $\mathrm{CO}_{2} \mathrm{EOR}$ phase to improve recovery from hydrocarbon reservoirs in the future.

Simple boundary conditions for exploration have been set for geothermal CCUS at depth of more than $2000 \mathrm{~m}$ and less than $4000 \mathrm{~m}$ (Fig. 5). Deeper targets give higher temperatures but drilling is more expensive and productivity usually diminishes because of decreasing porosity and permeability with

depth. Using these simple criteria for a first screening identifies many potential targets for in-depth studies, exploration and eventually piloting.

\subsection{Status, Potential and the Way Forward}

Massive efforts of CCS and CCUS are required quickly in order to keep emissions of $\mathrm{CO}_{2}$ derived from the production of Arabian hydrocarbons (exported and consumed within Arabia) below levels leading to severe adverse climate change specifically in Arabia but also elsewhere. A real danger exists that subsurface hydrocarbon assets become stranded if carbon emissions are curbed worldwide to meet climate targets. On the other hand, geological conditions are diverse and excellent for the sequestration of $\mathrm{CO}_{2}$ and storage-for-reuse at the scale of gigatons that is required to offset the large emission levels. Point-sources of $\mathrm{CO}_{2}$ are many. Technology of capturing $\mathrm{CO}_{2}$ at point source is available and being optimized to increase efficiency and decrease costs. However, despite the massive need and the high potential for CCS/CCUS, little concrete efforts are ongoing to reduce uncertainties for sequestering or storing $\mathrm{CO}_{2}$ in the subsurface at large scale. Two small $\mathrm{CO}_{2}$ EOR pilot projects executed by National Oil Companies are the only concrete efforts.

A major roadblock to effectively research the potential for CCS and CCUS and prepare the way forward for pilots and economic developments is the lack of publicly available subsurface data. A vast quantity of subsurface data has been acquired over the last 50 years in pursuit of hydrocarbon exploration and production. The availability of this data to the research communities and investors will allow faster development of CSS and CCUS. Considering that large scale CCS and CCUS projects will take years to develop and that the world emits some 35-40 $\mathrm{Gt} / \mathrm{y} \mathrm{CO}_{2}$ against a remaining budget of about $550 \mathrm{Gt}$, time is running out quickly to prevent either catastrophic climate change or energy shortage and stranded hydrocarbon assets.

\section{Conclusions}

Countries of the Arabian Peninsula have reported so far only a couple of pilot projects towards CCS and CCUS despite being main contributors to $\mathrm{CO}_{2}$ production worldwide. Fast development of CCS and CCUS contributes to the success of the ambition and goals of Arabian countries to combat the negative impact of $\mathrm{CO}_{2}$ emissions on climate (e.g. Vision 2030 of KSA). Furthermore, mitigating $\mathrm{CO}_{2}$ produced from hydrocarbon utilization is crucial to maintain the viability of hydrocarbon assets to stay competitive with alternative energy sources and avoid catastrophic climate change. These hydrocarbon assets are expected to remain the main contributor to the GDP of Arabian countries, and therefore promoting CCS and CCUS is an urgent need. 
Arabia is blessed with excellent opportunities for large scale CCS and CCUS in a variety of geological settings:

- The eastern plate margin along the Arabian Gulf offers multiple stacked aquifers with seals and suitable structures for safe long-term $\mathrm{CO}_{2}$ storage. Notably, Mesozoic carbonate aquifers are extremely well known in their extent, depth, composition and petrophysical properties through the extensive exploration and production of hydrocarbons. Seals of proven capacity and extent are well known (e.g. Hith anhydrite, Nahr Umr shales); others exist too.

- The western plate margin contains deep rift basins which are less explored but are likely to contain significant aquifers in the synrift clastics and patchy carbonate platforms. Shales and thick evaporites are likely to provide excellent seals to safely store $\mathrm{CO}_{2}$.

- Thick basalt flows of Western Arabia and basalt, gabbro and peridotite sequences of Eastern Arabia (the Semail Ophiolite of Oman and UAE) provide opportunities for CCS using mineral alteration processes and CarbFix technologies.

Arabia probably offers some of the most promising potential for utilizing sequestered $\mathrm{CO}_{2}$ for desalination, district cooling and electricity production via geothermal heat extraction. The multiple stacked aquifers, the presence of suitable seals and the favorable setting of gentle anticlinal structures combined with large numbers of $\mathrm{CO}_{2}$ point sources are all ideal for optimized geothermal heat extraction. The development and large-scale deployment of CCUS technology promise a steady revenue stream from stored $\mathrm{CO}_{2}$ and also provides $\mathrm{CO}_{2}$ reservoirs for a late-stage $\mathrm{CO}_{2}$ EOR phase to improve recovery from hydrocarbon reservoirs in the future.

Finally, a major roadblock to effectively research the potential for CCS and CCUS and prepare the way for pilots and economic development is the lack of publicly available subsurface data. The availability of data that has been acquired over the last 50 years from hydrocarbon exploration and production will be crucial to the development of geological-based solutions to reduce, recover, reuse, and recycle" $\mathrm{CO}_{2}$.

\section{Acknowledgements}

We thank members of the $\mathrm{CO}_{2}$ and geothermal working groups at KAUST for valuable input and discussions, in particular KAUST Faculty Martin Mai and Thomas Finkbeiner, Dr. Jakub Fedorik, Miliausha Petrova, and Eduardo Torres. Sarima Vahrenkamp and Michael Oyinloye are thanked and acknowledged for their contribution to carbon data collation and evaluation. The research is funded by baseline support to KAUST faculty Vahrenkamp, Afifi and Hoteit.

\section{References}

1. Saderne V, Fusi M, Thomson T, Dunne A, Mahmud F, Roth F, et al. Total alkalinity production in a mangrove ecosystem reveals an overlooked Blue Carbon component. Limnol Oceanogr Lett. 2020.

2. Buis A. Examining the Viability of Planting Trees to Help Mitigate Climate Change. NASA Global climate change: https://climatenasagov/news/2927/examining-the-viability-of-planting-trees-to-help-mitigate-climate-change.

3. Global Change Data Lab. Our world in data. https://ourworldindataorg/per-capita-co2. 2012.

4. Dasgupta S, Laplante B, Meisner C, Wheeler D, Yan J. The Impact of Sea Level Rise on Developing Countries: A Comparative Analysis. Policy Research Working Paper; No 4136 World Bank, Washington, DC @ W World Bank https://openknowledgeworldbankorg/handle/10986/7174 License: CC BY 30 IGO. 2007.

5. Howarth N, Odnoletkova N, Alshehri T, Almadani A, Lanza A, Patzek T. Staying Cool in A Warming Climate: Temperature, Electricity and Air Conditioning in Saudi Arabia. Climate. 2020;8(1):4.

6. IPCC. Climate Change 2007: Synthesis Report. Contribution of Working Groups I, II and III to the Fourth Assessment Report of the Intergovernmental Panel on Climate Change [Core Writing Team, Pachauri, R. K and Reisinger, A.]. IPCC, Geneva, Switzerland. $2007: 104$ pp.

7. Temizel C, Irani M, Canbaz CH, Palabiyik Y, Moreno R, Balikcioglu A, et al. Technical and Economical Aspects of Use of Solar Energy in Oil \& Gas Industry in the Middle East. SPE International Heavy Oil Conference and Exhibition; 2018. D022S028R001.

8. Liu HW, Tellez BG, Atallah T, Barghouty M. The role of CO2 capture and storage in Saudi Arabia's energy future. Int J Greenh Gas Con. 2012;11:163-71.

9. Randolph JB, Saar MO. Combining geothermal energy capture with geologic carbon dioxide sequestration. Geoph Res Lett. $2011 ; 38$.

10. Aycaguer AC, Lev-On M, Winer AM. Reducing carbon dioxide emissions with enhanced oil recovery projects: A life cycle assessment approach. Energ Fuel. 2001;15(2):303-8.

11. Bachu S. Identification of oil reservoirs suitable for CO2-EOR and CO2 storage (CCUS) using reserves databases, with application to Alberta, Canada. Int J Greenh Gas Con. 2016;44:152-65.

12. Núñez-López V, Gil-Egui R, Hosseini SA. Environmental and Operational Performance of CO2-EOR as a CCUS Technology: A Cranfield Example with Dynamic LCA Considerations. Energies. 2019;12(3):448. 
13. Adams BM, Kuehn TH, Bielicki JM, Randolph JB, Saar MO. A comparison of electric power output of CO2 Plume Geothermal (CPG) and brine geothermal systems for varying reservoir conditions. Appl Energ. 2015;140:365-77.

14. BP. BP Statistical Review of World Energy 2020 (Tech. Rep.). https://wwwbpcom/content/dam/bp/businesssites/en/global/corporate/pdfs/energy-economics/statistical-review/bp-stats-review-2020-full-reportpdf\%2013. 2020.

15. U. S. Energy Information Adminsitration. Worldometer. https://wwwworldometersinfo/energy/. 2021.

16. US Environmental Protection Agency. Greenhouse gas equivalency calculator. https://wwwepagov/energy/greenhouse-gases-equivalenciescalculator-calculations-and-references 2021.

17. Air Pollution and Climate Secretariat. How much more can be emitted? https://wwwairclimorg/how-much-more-can-beemitted\#: :text=The\%20IPCC\%20report\%20suggests\%20that,the\%20rest\%20of\%20this\%20century. 2021.

18. AlOtaibi ZS, Khonkar HI, AlAmoudi AO, Alqahtani SH. Current status and future perspectives for localizing the solar photovoltaic industry in the Kingdom of Saudi Arabia. Energy Transitions. 2020;4(1):1-9.

19. Allhibi H, Chowdhury H, Zaid M, Loganathan B, Alam F. Prospect of wind energy utilization in Saudi Arabia: A review. 2nd International Conference on Energy and Power (Icep2018). 2019;160:746-51.

20. Al-Hajeri S, Negahban S, Bin-dhaaer G, Almesmari A. Design and Implementation of the first CO2-EOR Pilot in Abu Dhabi. 2010.

21. Alhashboul A, Almufti A, Kokal S. Surface Facilities Design for the First CO2 EOR Demonstration Project in Saudi Arabia. SPE Europec featured at 79th EAGE Conference and Exhibition; 2017. D031S008R003.

22. ARAMCO. Carbon, Capture, Utilization and Storage. https://wwwaramcocom/en/making-a-difference/planet/carbon-capture-utilization-andstorage\#. 2021.

23. Neele F, Vandeweijer V, Mayyan H, Sharma SR, Kamal D. Options for CO2 sequestration in Kuwait. 13th International Conference on Greenhouse Gas Control Technologies, Ghgt-13. 2017;114:2827-35.

24. Ladbrook B, Smith N, Pershad H, Harland K, Slater S, Holloway S, et al. CO2 Storage in Depleted Gas Fields. EA Technical Report Available online: https://hubglobalccsinstitutecom/sites/default/files/publications/95786/co2-storage-depleted-gas-fieldspdf.2009.

25. Holtz MH. Residual Gas Saturation to Aquifer Influx: A Calculation Method for 3-D Computer Reservoir Model Construction. SPE Gas Technology Symposium; 2002. SPE-75502-MS.

26. Hydrocarbon Processing. ADNOC announces expansion of carbon capture program. https://wwwhydrocarbonprocessingcom/news/2020/02/adnoc-announces-expansion-of-carbon-capture-program. 2020.

27. Dai ZX, Viswanathan H, Middleton R, Pan F, Ampomah W, Yang CB, et al. CO2 Accounting and Risk Analysis for CO2 Sequestration at Enhanced Oil Recovery Sites. Environ Sci Technol. 2016;50(14):7546-54.

28. Sharland PR, Archer R, Casey DM, Davies RB, Hall SH, Heward AP, et al. Arabian Plate Sequence Stratigraphy. GeoArabia Special Publication, Gulf PetroLink, Bahrain. 2001;2:371.

29. Konert G, Al-Hajri SA, Al Naim AA, Afifi AM, de Groot K, Droste HJ. Paleozoic stratigraphy and hydrocarbon habitat of the Arabian plate. Aapg Memoir. 2002;74:483-515.

30. Birkle P, Jenden PD, Al-Dubaisi JM. Origin of formation water from the Unayzah and Khuff petroleum reservoirs, Saudi Arabia. Proced Earth Plan Sc. 2013;7:77-80.

31. Bosworth W, Huchon P, McClay K. The Red Sea and Gulf of Aden basins. J Afr Earth Sci. 2005;43(1-3):334-78.

32. Polis SR, Angelich MT, Beeman CR, Maze WB, Reynolds DJ, Steinhauff DM, et al. Preferential deposition and preservation of structurallycontrolled synrift reservoirs: Northeast Red Sea and Gulf of Suez. Geoarabia. 2005;10(1):97-124.

33. Tubbs RE, Fouda HGA, Afifi AM, Raterman NS, Hughes GW, Fadolalkarem YK. Midyan Peninsula, northern Red Sea, Saudi Arabia: Seismic imaging and regional interpretation. Geoarabia. 2014;19(3):165-84.

34. Camp VE, Roobol MJ, Hooper PR. The Arabian Continental Alkali Basalt Province .3. Evolution of Harrat Kishb, Kingdom of SaudiArabia. Geol Soc Am Bull. 1992;104(4):379-96.

35. Gislason SR, Sigurdardottir H, Aradottir ES, Oelkers EH. A brief history of CarbFix: Challenges and victories of the project's pilot phase. Enrgy Proced. 2018;146:103-14.

36. Jagoutz O, Macdonald FA, Royden L. Low-latitude arc-continent collision as a driver for global cooling. P Natl Acad Sci USA. 2016;113(18):4935-40.

37. Aldega L, Carminati E, Scharf A, Mattern F, Al-Wardi M. Estimating original thickness and extent of the Semail Ophiolite in the eastern Oman Mountains by paleothermal indicators. Mar Petrol Geol. 2017;84:18-33.

38. Breton JP, Bechennec F, Le Metour J, Moen-Maurel L, Razin P. Eoalpine (Cretaceous) evolution of the Oman Tethyan continental margin: Insights from a structural field study in Jabal Akhdar (Oman Mountains). Geoarabia. 2004;9(2):41-58.

39. Paukert AN, Matter JM, Kelemen PB, Shock EL, Havig JR. Reaction path modeling of enhanced in situ CO2 mineralization for carbon sequestration in the peridotite of the Samail Ophiolite, Sultanate of Oman. Chem Geol. 2012;330:86-100.

40. Kelemen PB, Aines R, Bennett E, Benson SM, Carter E, Coggon JA, et al. In situ carbon mineralization in ultramafic rocks: Natural processes and possible engineered methods. Enrgy Proced. 2018;146:92-102.

41. Gislason S, Broecker WS, Gunnlaugsson E, Snæbjörnsdóttir SÓ, Mesfin K, Alfredsson H, et al. Rapid solubility and mineral storage of CO2 in basalt. Energy Procedia. 2014;63:4561-74.

42. Schulz S. Experimental and numerical studies on the water balance of the Upper Mega Aquifer system, Arabian Peninsula. 2017.

43. Pollastro, R. Total Petroleum Systems of the Paleozoic and Jurassic, Greater Ghawar Uplift and Adjoining Provinces of Central Saudi Arabia and Northern Arabian-Persian Gulf. 2003; USGS Publication; https://doi.org/10.3133/b2202H 